\title{
Effect of Zinc and Sulphur on Growth, Yield and Economics of Clusterbean [Cyamopsis tetragonoloba (L.) Taub.]
}

\author{
Sunil, Seema Dahiya, M.S. Bhattoo and Rajbir Singh Khedwal
}

Chaudhary Charan Singh Haryana Agricultural University, Hisar- 125001, Haryana, India

*Corresponding author

\section{Keywords}

Clusterbean, N, P, S and $\mathrm{Zn}$ doses, Growth, Yield, Economics.

\section{Article Info}

Accepted:

26 September 2017

Available Online:

10 November 2017

\section{A B S T R A C T}

A field experiment was conducted during Kharif 2015 at cotton research station, Sirsa, CCS HAU, Hisar (India). The experiment was conducted in RBD with three replications. The experiment consist of 16 treatments in which $\mathrm{N}$ and $\mathrm{P}$ were applied as per recommended dose $\left(\mathrm{N}=20 \mathrm{~kg} / \mathrm{ha}, \mathrm{P}_{2} \mathrm{O}_{5}=40 \mathrm{~kg} / \mathrm{ha}\right)$ along with different doses of $\mathrm{Zn}(10$, 20 and $30 \mathrm{~kg} / \mathrm{ha}$ ) and $\mathrm{S}(20,30$ and $40 \mathrm{~kg} / \mathrm{ha})$ and their combinations. Growth parameters viz. plant population, plant height and dry matter accumulation were recorded maximum in $\mathrm{T}_{16}$ (N@20 kg+ $\mathrm{P}_{2} \mathrm{O}_{5} @ 40 \mathrm{~kg}+\mathrm{ZnSO}_{4} @ 30 \mathrm{~kg}+\mathrm{S} @ 40 \mathrm{~kg} / \mathrm{ha}$ ). Yield attributes viz.no. of pods/plant, no. of grains/pod, Yield viz. grain and straw yield were also recorded highest in $\mathrm{T}_{16}$, while maximum harvest index was observed in $\mathrm{T}_{8}$ (N @ $20 \mathrm{~kg}+\mathrm{P}_{2} \mathrm{O}_{5} @ 40 \mathrm{~kg}+$ $\mathrm{ZnSO}_{4} @ 10 \mathrm{~kg}+\mathrm{S} @ 20 \mathrm{~kg} / \mathrm{ha}$ ) and highest 1000 grains weight (test weight) was observed in $\mathrm{T}_{13}$ (N@20 kg + $\mathrm{P}_{2} \mathrm{O}_{5}$ @ $40 \mathrm{~kg}+\mathrm{ZnSO}_{4} @ 20 \mathrm{~kg}+\mathrm{S} @ 40 \mathrm{~kg} / \mathrm{ha}$ ) as compared to other nutrient treatments. In clusterbean, cost of cultivation and gross returns were recorded highest in $\mathrm{T}_{16}$, while $\mathrm{T}_{10}$ recorded highest net returns and $\mathrm{B}$ : $\mathrm{C}$ than other nutrient treatments. All the parameters were recorded lowest in control treatments. It may be concluded that $T_{16}$ resulted in better growth parameters, yield attributes, yield and economics except harvest index higher in $\mathrm{T}_{8}$, and net returns higher in $\mathrm{T}_{10}$. Increased in growth and yield parameter was observed, further study can be explored to optimize the nutrient requirement for yield maximization, profitability and sustainability.

\section{Introduction}

Clusterbean (Cyamopsis tetragonoloba L. Taub.) popularly known as guar, is a drought hardy and deep rooted legume crop grown for feed, fodder, green manure and vegetable purpose. Guar plant produces a cluster of flowers and pods, therefore, it is also known as cluster bean. It belongs to the family Leguminaceae and subfamily Papilinaceae and is known to improve soil fertility. Being a legume crop, it has the capacity to fix atmospheric nitrogen by its effective root nodules (Kumhar et al., 2012). It is generally
$50-100 \mathrm{~cm}$ tall and bears 4 to 10 branches (branch type). However, non-branch type varieties have main stem only, which is heavily clustered with pods.

India leads among the major guar producing countries of the world, contributing around 75 to $80 \%$ to the world's total production ( 7.5 to 10 lakhs tonnes) (Annonymous, 2012). It is an important cash crop of south-west (SW) Haryana as it is second largest producer of clusterbean having area 2.15 lakh hactare, 
with production of 2.9 lakh tones and productivity of $1348 \mathrm{~kg} / \mathrm{ha}$ which is maximum in the country (Annonymous, 2013). According to Aykroyd (1963) the composition of clusterbean is $8.10 \mathrm{~g}$ moisture, $10.8 \mathrm{~g}$ carbohydrate, $23 \%$ protein, $1.4 \mathrm{~g}$ fat, $1.4 \mathrm{~g}$ minerals, $0.09 \mathrm{mg}$ thiamine, $0.03 \mathrm{mg}$ riboflavin, 47 I.U. vitamin C, 316 I.U, vitamin $\mathrm{A}$ (per $100 \mathrm{~g}$ of edible portion).

The potential yield of most of the varieties ranges from 18-20 q/ha but the average yield productivity of the country is less than potential average. This may be ascribed to many reasons but inadequate and imbalanced fertilization is the major factor. Sulphur plays an important role in synthesis of $\mathrm{S}$ containing amino acid and thus not only increases the crop yield but also improves the crop quality. Clusterbean is highly responsive crop to micronutrients. The micronutrient in general and zinc in particular. Zinc is required for plant growth, as an activator of several enzymes and is directly involved in the biosynthesis of growth regulators such as auxin which promotes production of more plant cells and biomass that will be stored in the plant organs especially in seeds and their deficiencies may be one of the important reasons of poor yields in light textured soils (Singh and Raj, 2001). The work undertaken on these aspects in clusterbean is very meagre. Therefore, keeping this in view a study was conducted on effect of zinc and sulphur on growth and yields of clusterbean.

\section{Materials and Methods}

A field experiment was conducted during kharif 2015 at Cotton Research Station, Sirsa, CCS HAU, Hisar (India) situated at $29^{\circ} 25^{\prime} \mathrm{N}$ latitude, $74^{\circ} 40^{\prime} \mathrm{E}$ longitude and at an altitude of $202 \mathrm{~m}$ above mean sea level. The soil of the experimental field was loamy sand, slightly alkaline in reaction, low in organic carbon $(0.35 \%)$ and nitrogen, medium in phosphorus, low in zinc and sulphur. The values of available $\mathrm{N}$ (kg/ha), P (kg/ha), Zn (mg/ha) and $\mathrm{S}(\mathrm{kg} / \mathrm{ha})$ were $137,13.4,1.2$, 9.82 and 133, 10.8, 1.01, 8.9 before sowing and 137, 13.4, 1.3, 11.6 and 133, 10.8, 1.07, 10.5 after harvest at $0-15$ and $15-30 \mathrm{~cm}$ soil depth respectively.

During the crop growing period, the mean weekly temperature values ranged between 30 to $43{ }^{\circ} \mathrm{C}$ and 13 to $27{ }^{\circ} \mathrm{C}$ for maximum and minimum temperatures. The rainfall received was $205.07 \mathrm{~mm}$ during the crop growing period. The experiment was conducted in RBD with three replications. The experiment consist of 16 treatments in which $\mathrm{N}$ and $\mathrm{P}$ were applied as per recommended dose (RNP: $\mathrm{N}=20 \mathrm{~kg} / \mathrm{ha}, \mathrm{P}_{2} \mathrm{O}_{5}=40 \mathrm{~kg} / \mathrm{ha}$ ) along with different doses of $\mathrm{Zn}(10,20$ and $30 \mathrm{~kg} / \mathrm{ha})$ and $\mathrm{S}(20,30$ and $40 \mathrm{~kg} / \mathrm{ha})$ and their combinations. The sowing of clusterbean variety HG-2-20 was done on $14^{\text {th }}$ July, 2015 using seed rate of $15 \mathrm{~kg} / \mathrm{ha}$. Other agricultural practices were as per package of practices, CCS HAU, Hisar. The cropping history of the experimental field for the five years period prior to the present investigation is as under:

\section{Results and Discussion}

\section{Effect of $\mathrm{Zn}$ and $\mathrm{S}$ on growth}

Plant population differed with different nutrient treatments ( $\mathrm{Zn}$ and $\mathrm{S}$ ) and maximum plant population was recorded with the application of $\mathrm{T}_{16}\left(\mathrm{RNP}+\mathrm{ZnSO}_{4} @ 30 \mathrm{~kg}+\mathrm{S}\right.$ @ $40 \mathrm{~kg} / \mathrm{ha}$ ), but it was at par with $\mathrm{T}_{15}, \mathrm{~T}_{14}$ and $\mathrm{T}_{12}$ and the lowest value was obtained in $\mathrm{T}_{1}$ (Table 2). Increase in plant population with increase in $\mathrm{Zn}$ and $\mathrm{S}$ doses was due to the reason that $\mathrm{Zn}$ and $\mathrm{S}$ application created a balanced nutritional environment in the rhizosphere which enhanced metabolic activities and photosynthetic rate, resulting in improvement in plant stand and helps in maintaining plant population. 
Plant height is an index of plant growth and it increased with advancement of crop growth. The higher doses of $\mathrm{Zn}$ and $\mathrm{S}$ increased the plant height over control. The maximum plant height $(74.90 \mathrm{~cm})$ was obtained from application of $\mathrm{T}_{16}\left(\mathrm{RNP}+\mathrm{ZnSO}_{4} @ 30 \mathrm{~kg}+\mathrm{S}\right.$ @ $40 \mathrm{~kg} / \mathrm{ha}$ ) as compared to the other nutrient treatments, while at par with $\mathrm{T}_{13}(\mathrm{RNP}+$ $\left.\mathrm{ZnSO}_{4} @ 20 \mathrm{~kg}+\mathrm{S} @ 40 \mathrm{~kg} / \mathrm{ha}\right)(74.86 \mathrm{~cm})$ and $\mathrm{T}_{15}\left(\mathrm{RNP}+\mathrm{ZnSO}_{4} @ 30 \mathrm{~kg}+\mathrm{S} @ 30\right.$ $\mathrm{kg} / \mathrm{ha})(74.86 \mathrm{~cm})$. It was because the availability of $\mathrm{Zn}$ and $\mathrm{S}$ have stimulated the metabolic and enzymatic activity thereby increasing the plant height. Sulphur is constituent of glutathion, a compound supposed to play a part in plant respiration, hence increase plant height (Jordon and Reisenaur, 1957) and Zn play key role in stabilizing RNA and DNA structure and involves in biosynthesis of growth promoting hormones such as IAA and gibberellins (Mousavi, 2011). These results were in agreement with the findings of Kasturikrishna and Ahlawat (2000), Baviskar et al., (2012), Ramawtar et al., (2013). Addition of Zinc increases the plant height (Singh et al., 2014).

The accumulation of dry matter in clusterbean is a good index to express the photosynthetic efficiency of the plants. The dry matter accumulation per plant was influenced due to different nutrient treatments ( $\mathrm{Zn}$ and $\mathrm{S}$ ) and significantly higher dry matter accumulation
$26.52 \mathrm{~g} /$ plant was obtained by applying $\mathrm{T}_{16}$ $\left(\mathrm{RNP}+\mathrm{ZnSO}_{4} @ 30 \mathrm{~kg}+\mathrm{S} @ 40 \mathrm{~kg} / \mathrm{ha}\right)$ which was significantly superior to rest of treatments, but at par with $\mathrm{T}_{13}\left(\mathrm{RNP}+\mathrm{ZnSO}_{4}\right.$ @20 kg + S @40 kg/ha) (26.35 g/plant) and $\mathrm{T}_{10}\left(\mathrm{RNP}+\mathrm{ZnSO}_{4} @ 10 \mathrm{~kg}+\mathrm{S} @ 40 \mathrm{~kg} / \mathrm{ha}\right)$ (26.23 g/plant) because Zn and S application created a balanced nutritional environment which enhanced metabolic activities and photosynthetic rate, resulting in improvement in plant height and ultimately accumulation of dry matter. Similar types of results were reported by Meena et al., (2006), Ramawtar et al., (2013).

\section{Effect of $\mathrm{Zn}$ and $\mathrm{S}$ on yield attributes and yields}

Successive increase in sulphur and zinc fertilization up to 40 and $30 \mathrm{~kg} / \mathrm{ha}$ respectively, significantly improved the yield attributes viz., no. of pods/plant, no. of grains/pod, test weight; and grain and straw yield of clusterbean (Table 2). The number of pods/plant was significantly influenced due to $\mathrm{Zn}$ and $\mathrm{S}$ levels and the highest number of pods per plant (43.73) was recorded with $\mathrm{T}_{16}$ $\left(\mathrm{RNP}+\mathrm{ZnSO}_{4} @ 30 \mathrm{~kg}+\mathrm{S} 40 \mathrm{~kg} / \mathrm{ha}\right)$ as compared to rest of the treatments, but it was at par with $\mathrm{T}_{13}\left(\mathrm{RNP}+\mathrm{ZnSO}_{4} @ 20 \mathrm{~kg}+\mathrm{S} @\right.$ $40 \mathrm{~kg} / \mathrm{ha}$ ). The number of grains per pod increased with successive increase in doses of $\mathrm{Zn}$ and $\mathrm{S}$

Table.1 Cropping history of the experimental field

\begin{tabular}{|c|c|c|}
\hline Year & Kharif & Rabi \\
\hline $2010-2011$ & Clusterbean & Wheat \\
\hline $2011-2012$ & Cotton & Wheat \\
\hline $2012-2013$ & Cotton & Wheat \\
\hline $2013-2014$ & Cotton & Wheat \\
\hline $2014-2015$ & Clusterbean & Wheat \\
\hline $2015-2016$ & Clusterbean (Experimental crop) & - \\
\hline
\end{tabular}


Table.2 Effect of different nutrient treatments on growth, yield attributes and yields of clusterbean

\begin{tabular}{|c|c|c|c|c|c|c|c|c|c|}
\hline Treatments & $\begin{array}{c}\text { Plant } \\
\text { Population } \\
\text { (per plot) }\end{array}$ & $\begin{array}{l}\text { Plant } \\
\text { heigh } \\
\text { t (cm) }\end{array}$ & $\begin{array}{c}\text { Dry matter } \\
\text { accumulatio } \\
\text { n (g/plant) }\end{array}$ & $\begin{array}{l}\text { No. of } \\
\text { pods/ } \\
\text { plant }\end{array}$ & $\begin{array}{c}\text { No. of } \\
\text { grain/ } \\
\text { pod }\end{array}$ & $\begin{array}{c}1000 \\
\text { grains } \\
\text { weight }(\mathrm{g}) \\
\end{array}$ & $\begin{array}{c}\text { Grain } \\
\text { yield } \\
\text { (kg/ha) }\end{array}$ & $\begin{array}{c}\text { Straw } \\
\text { yield } \\
\text { (kg/ha) }\end{array}$ & $\begin{array}{c}\text { Harves } \\
t \text { index } \\
(\%)\end{array}$ \\
\hline $\mathbf{T}_{1}(\mathrm{RNP})$ & 402 & 67.81 & 21.00 & 32.22 & 6.33 & 29.25 & 801 & 2498 & 24.28 \\
\hline $\mathbf{T}_{2}\left(\mathrm{RNP}+\mathrm{ZnSO}_{4} @ 10 \mathrm{~kg} / \mathrm{ha}\right)$ & 406 & 68.83 & 21.63 & 33.35 & 6.67 & 29.35 & 841 & 2586 & 24.55 \\
\hline $\mathbf{T}_{3}\left(\mathrm{RNP}+\mathrm{ZnSO}_{4} @ 20 \mathrm{~kg} / \mathrm{ha}\right)$ & 410 & 69.85 & 22.20 & 34.00 & 7.33 & 29.35 & 857 & 2641 & 24.51 \\
\hline $\mathbf{T}_{4}\left(\mathrm{RNP}+\mathrm{ZnSO}_{4} @ 30 \mathrm{~kg} / \mathrm{ha}\right)$ & 418 & 70.05 & 22.68 & 34.22 & 8.33 & 29.45 & 873 & 2656 & 24.74 \\
\hline $\mathbf{T}_{5}\left(\mathrm{RNP}+\mathrm{S}^{*} @ 20 \mathrm{~kg} / \mathrm{ha}\right)$ & 418 & 71.54 & 23.84 & 37.28 & 7.00 & 30.15 & 958 & 2753 & 25.82 \\
\hline $\mathbf{T}_{6}(\mathrm{RNP}+\mathrm{S} * @ 30 \mathrm{~kg} / \mathrm{ha})$ & 415 & 74.46 & 23.82 & 37.65 & 8.00 & 28.55 & 988 & 2893 & 25.45 \\
\hline $\mathbf{T}_{7}(\mathrm{RNP}+\mathrm{S} * @ 40 \mathrm{~kg} / \mathrm{ha})$ & 416 & 74.59 & 24.51 & 41.73 & 9.00 & 30.20 & 998 & 2960 & 25.20 \\
\hline $\mathbf{T}_{\mathbf{8}}\left(\mathrm{RNP}+\mathrm{ZnSO}_{4} @ 10 \mathrm{~kg}+\mathrm{S} @ 20 \mathrm{~kg} / \mathrm{ha}\right)$ & 419 & 71.75 & 24.59 & 39.31 & 7.67 & 30.10 & 978 & 2798 & 25.89 \\
\hline $\mathbf{T}_{\mathbf{9}}\left(\mathrm{RNP}+\mathrm{ZnSO}_{4} @ 10 \mathrm{~kg}+\mathrm{S} @ 30 \mathrm{~kg} / \mathrm{ha}\right)$ & 422 & 74.66 & 25.73 & 40.60 & 8.00 & 30.15 & 1017 & 3035 & 25.10 \\
\hline $\mathbf{T}_{10}\left(\mathrm{RNP}+\mathrm{ZnSO}_{4} @ 10 \mathrm{~kg}+\mathrm{S} @ 40 \mathrm{~kg} / \mathrm{ha}\right)$ & 420 & 74.80 & 26.23 & 43.02 & 9.00 & 30.15 & 1034 & 3075 & 25.15 \\
\hline $\mathbf{T}_{11}\left(\mathrm{RNP}+\mathrm{ZnSO}_{4} @ 20 \mathrm{~kg}+\mathrm{S} @ 20 \mathrm{~kg} / \mathrm{ha}\right)$ & 418 & 71.88 & 24.80 & 39.80 & 7.67 & 30.00 & 980 & 2821 & 25.78 \\
\hline $\mathbf{T}_{12}\left(\mathrm{RNP}+\mathrm{ZnSO}_{4} @ 20 \mathrm{~kg}+\mathrm{S} @ 30 \mathrm{~kg} / \mathrm{ha}\right)$ & 423 & 74.73 & 25.94 & 40.99 & 8.67 & 30.10 & 1036 & 3115 & 24.95 \\
\hline $\mathbf{T}_{13}\left(\mathrm{RNP}+\mathrm{ZnSO}_{4} @ 20 \mathrm{~kg}+\mathrm{S} @ 40 \mathrm{~kg} / \mathrm{ha}\right)$ & 424 & 74.86 & 26.35 & 43.40 & 9.00 & 30.30 & 1059 & 3142 & 25.21 \\
\hline $\mathbf{T}_{14}\left(\mathrm{RNP}+\mathrm{ZnSO}_{4} @ 30 \mathrm{~kg}+\mathrm{S} @ 20 \mathrm{~kg} / \mathrm{ha}\right)$ & 425 & 72.02 & 24.99 & 40.12 & 8.00 & 30.25 & 984 & 2873 & 25.51 \\
\hline $\mathbf{T}_{15}\left(\mathrm{RNP}+\mathrm{ZnSO}_{4} @ 30 \mathrm{~kg}+\mathrm{S} @ 30 \mathrm{~kg} / \mathrm{ha}\right)$ & 425 & 74.86 & 26.10 & 41.31 & 9.00 & 30.25 & 1060 & 3120 & 25.35 \\
\hline $\mathbf{T}_{16}\left(\mathrm{RNP}+\mathrm{ZnSO}_{4} @ 30 \mathrm{~kg}+\mathrm{S} @ 40 \mathrm{~kg} / \mathrm{ha}\right)$ & 426 & 74.90 & 26.52 & 43.73 & 9.00 & 30.25 & 1062 & 3145 & 25.23 \\
\hline SEm \pm & 1 & 0.02 & 0.13 & 0.18 & 0.10 & 0.07 & 1.97 & 2.34 & 0.002 \\
\hline $\mathrm{CD}$ at $5 \%$ & 4 & 0.05 & 0.37 & 0.52 & 0.57 & 0.21 & 5.72 & 6.78 & 0.005 \\
\hline
\end{tabular}

Note: In all treatments, $\mathrm{N}$ and $\mathrm{P}_{2} \mathrm{O}_{5}$ doses are as per recommendation (RNP: $\left.\mathrm{N}=20 \mathrm{~kg} / \mathrm{ha}, \mathrm{P}_{2} \mathrm{O}_{5}=40 \mathrm{~kg} / \mathrm{ha}\right)$, *= source of $\mathrm{S}$ was gypsum $(19 \% \mathrm{~S})$ and one plot $=$ $27 \mathrm{~m}^{2}$. 
Table.3 Effect of different nutrient treatments on economic of clusterbean

\begin{tabular}{|c|c|c|c|c|}
\hline Treatments & $\begin{array}{c}\text { Cost of } \\
\text { cultivation } \\
(\mathrm{Rs} / \mathrm{ha})\end{array}$ & $\begin{array}{c}\text { Gross } \\
\text { returns } \\
\text { (Rs/ha) }\end{array}$ & $\begin{array}{c}\text { Net } \\
\text { returns } \\
\text { (Rs/ha) }\end{array}$ & $\mathrm{B}: \mathrm{C}$ \\
\hline $\mathbf{T}_{1}(\mathrm{RNP})$ & 20054 & 39006 & 18952 & 1.94 \\
\hline $\mathbf{T}_{2}\left(\mathrm{RNP}+\mathrm{ZnSO}_{4} @ 10 \mathrm{~kg} / \mathrm{ha}\right)$ & 20494 & 40900 & 20406 & 2.00 \\
\hline $\mathbf{T}_{3}\left(\mathrm{RNP}+\mathrm{ZnSO}_{4} @ 20 \mathrm{~kg} / \mathrm{ha}\right)$ & 20934 & 41688 & 20754 & 1.99 \\
\hline $\mathbf{T}_{4}\left(\mathrm{RNP}+\mathrm{ZnSO}_{4} @ 30 \mathrm{~kg} / \mathrm{ha}\right)$ & 21374 & 42416 & 21042 & 1.98 \\
\hline $\mathbf{T}_{5}\left(\mathrm{RNP}+\mathrm{S}^{*} @ 20 \mathrm{~kg} / \mathrm{ha}\right)$ & 20654 & 46299 & 25645 & 2.24 \\
\hline $\mathbf{T}_{6}(\mathrm{RNP}+\mathrm{S} * @ 30 \mathrm{~kg} / \mathrm{ha})$ & 20954 & 47823 & 26869 & 2.28 \\
\hline $\mathbf{T}_{7}\left(\mathrm{RNP}+\mathrm{S}^{*} @ 40 \mathrm{~kg} / \mathrm{ha}\right)$ & 21254 & 48336 & 27082 & 2.27 \\
\hline $\mathbf{T}_{8}\left(\mathrm{RNP}+\mathrm{ZnSO}_{4} @ 10 \mathrm{~kg}+\mathrm{S} @ 20 \mathrm{~kg} / \mathrm{ha}\right)$ & 21049 & 47213 & 26164 & 2.24 \\
\hline $\mathbf{T}_{9}\left(\mathrm{RNP}+\mathrm{ZnSO}_{4} @ 10 \mathrm{~kg}+\mathrm{S} @ 30 \mathrm{~kg} / \mathrm{ha}\right)$ & 21349 & 50883 & 29534 & 2.38 \\
\hline $\mathbf{T}_{10}\left(\mathrm{RNP}+\mathrm{ZnSO}_{4} @ 10 \mathrm{~kg}+\mathrm{S} @ 40 \mathrm{~kg} / \mathrm{ha}\right)$ & 21649 & 51225 & 29576 & 2.37 \\
\hline $\mathbf{T}_{11}\left(\mathrm{RNP}+\mathrm{ZnSO}_{4} @ 20 \mathrm{~kg}+\mathrm{S} @ 20 \mathrm{~kg} / \mathrm{ha}\right)$ & 21444 & 47352 & 25908 & 2.21 \\
\hline $\mathbf{T}_{12}\left(\mathrm{RNP}+\mathrm{ZnSO}_{4} @ 20 \mathrm{~kg}+\mathrm{S} @ 30 \mathrm{~kg} / \mathrm{ha}\right)$ & 21744 & 51215 & 29471 & 2.36 \\
\hline $\mathbf{T}_{13}\left(\mathrm{RNP}+\mathrm{ZnSO}_{4} @ 20 \mathrm{~kg}+\mathrm{S} @ 40 \mathrm{~kg} / \mathrm{ha}\right)$ & 22044 & 51325 & 29281 & 2.33 \\
\hline $\mathbf{T}_{14}\left(\mathrm{RNP}+\mathrm{ZnSO}_{4} @ 30 \mathrm{~kg}+\mathrm{S} @ 20 \mathrm{~kg} / \mathrm{ha}\right)$ & 21839 & 47607 & 25768 & 2.18 \\
\hline $\mathbf{T}_{15}\left(\mathrm{RNP}+\mathrm{ZnSO}_{4} @ 30 \mathrm{~kg}+\mathrm{S} @ 30 \mathrm{~kg} / \mathrm{ha}\right)$ & 22139 & 51315 & 29176 & 2.32 \\
\hline $\mathbf{T}_{16}\left(\mathrm{RNP}+\mathrm{ZnSO}_{4} @ 30 \mathrm{~kg}+\mathrm{S} @ 40 \mathrm{~kg} / \mathrm{ha}\right)$ & 22439 & 51436 & 28997 & 2.29 \\
\hline
\end{tabular}

Note: In all treatments, $\mathrm{N}$ and $\mathrm{P}_{2} \mathrm{O}_{5}$ doses are as per recommendation (RNP: $\mathrm{N}=20 \mathrm{~kg} / \mathrm{ha}, \mathrm{P}_{2} \mathrm{O}_{5}=40 \mathrm{~kg} / \mathrm{ha}$ ), *= source of $\mathrm{S}$ was gypsum $(19 \% \mathrm{~S})$.

Fig.1 Per cent increase in grain and straw yield with the application of $\mathrm{Zn}$ and $\mathrm{S}$

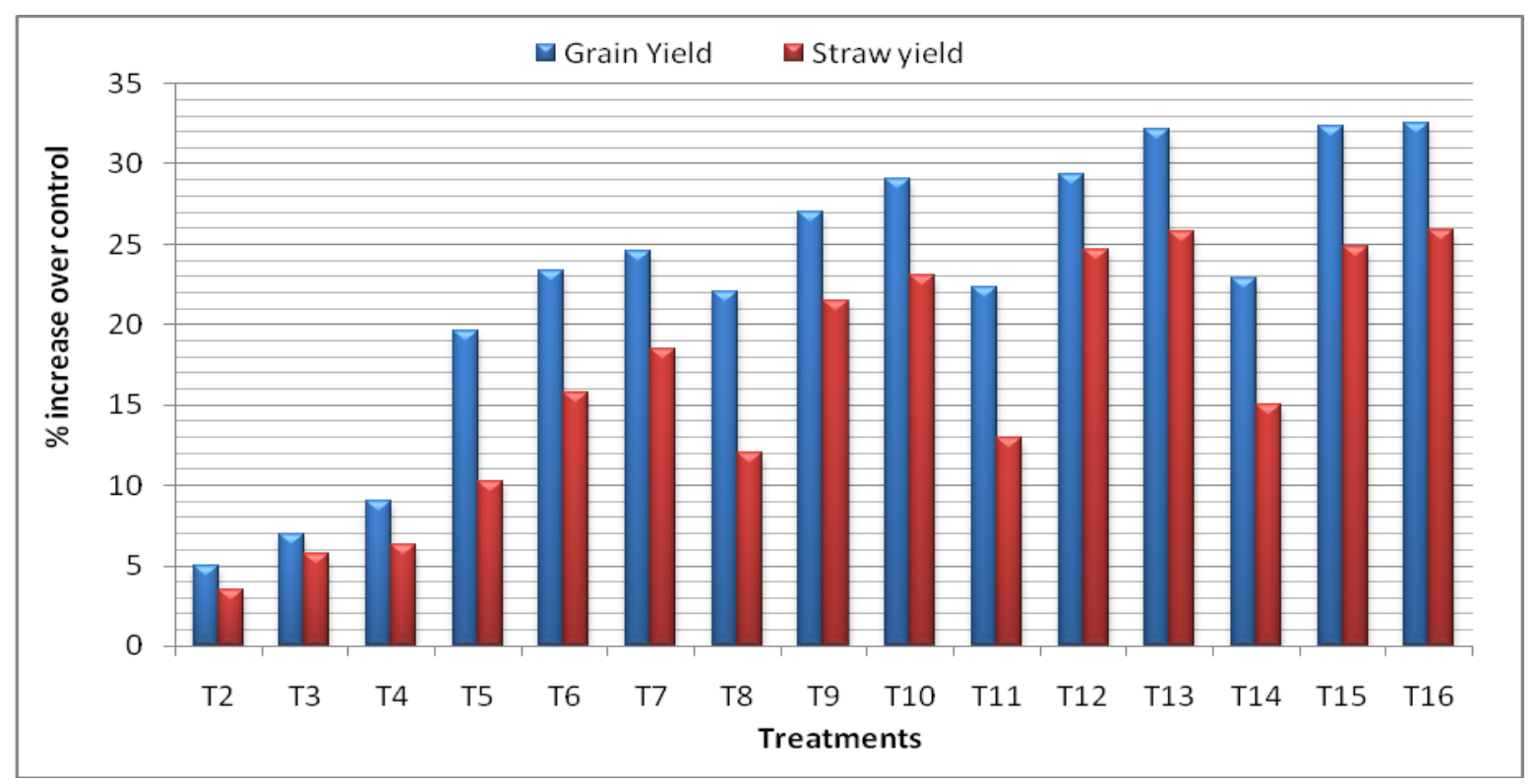

The highest numbers of grains per pod (9.00) was recorded with $\mathrm{T}_{16}\left(\mathrm{RNP}+\mathrm{ZnSO}_{4} @ 30\right.$ $\mathrm{kg}+\mathrm{S} @ 40 \mathrm{~kg} / \mathrm{ha}), \mathrm{T}_{15}\left(\mathrm{RNP}+\mathrm{ZnSO}_{4} @ 30\right.$ $\mathrm{kg}+\mathrm{S} @ 30 \mathrm{~kg} / \mathrm{ha}, \mathrm{T}_{13}\left(\mathrm{RNP}+\mathrm{ZnSO}_{4} @ 20\right.$ $\mathrm{kg}+\mathrm{S} @ 40 \mathrm{~kg} / \mathrm{ha}, \mathrm{T}_{10}\left(\mathrm{RNP}+\mathrm{ZnSO}_{4} @ 10\right.$
$\mathrm{kg}+\mathrm{S} @ 40 \mathrm{~kg} / \mathrm{ha}$ and $\mathrm{T}_{7}(\mathrm{RNP}+\mathrm{S} @ 40$ $\mathrm{kg} / \mathrm{ha}$ which were significantly higher over control (6.33). Numerically highest test weight $(30.30 \mathrm{~g})$ was obtained with application of $\mathrm{T}_{13}\left(\mathrm{RNP}+\mathrm{ZnSO}_{4} @ 20 \mathrm{~kg}+\mathrm{S}\right.$ 
@ $40 \mathrm{~kg} / \mathrm{ha}$ ) which was at par with $\mathrm{T}_{5}, \mathrm{~T}_{7}, \mathrm{~T}_{8}$, $\mathrm{T}_{9}, \mathrm{~T}_{10}, \mathrm{~T}_{12}, \mathrm{~T}_{14}, \mathrm{~T}_{15}$ and $\mathrm{T}_{16}$ while the lowest test weight was recorded with control (29.25 g).

The improvement in growth might be due to the fact that application of $\mathrm{S}$ improves overall nutritional environment in rhizosphere by improving not only the availability of $\mathrm{S}$, but it also reduced the $\mathrm{pH}$, which is the principle reason for availability and mobility of nutrients specially of $\mathrm{P}, \mathrm{Fe}, \mathrm{Mn}$ and $\mathrm{Zn}$ (Hilal and Abdelfattah, 1987). The improvement in nutritional environment ultimately resulted in better plant metabolism and photosynthetic activity improved yield components. The grain yield being the function of cumulative effect of yield attributes, increased significantly due to addition of $\mathrm{S}$.

Application of higher doses of $\mathrm{Zn}$ and $\mathrm{S}$ increased grain yield. Significantly higher grain yield $(1062 \mathrm{~kg} / \mathrm{ha})$ was recorded with application of $\mathrm{T}_{16}\left(\mathrm{RNP}+\mathrm{ZnSO}_{4} @ 30 \mathrm{~kg}+\mathrm{S}\right.$ @ $40 \mathrm{~kg} / \mathrm{ha}$ ) than other nutrient treatment, while it was at par with $\mathrm{T}_{15}\left(\mathrm{RNP}+\mathrm{ZnSO}_{4}\right.$ @30 kg+S@30 kg/ha (1060 kg/ha) and $\mathrm{T}_{13}$ $\left(\mathrm{RNP}+\mathrm{ZnSO}_{4} @ 20 \mathrm{~kg}+\mathrm{S} @ 40 \mathrm{~kg} / \mathrm{ha}(1059\right.$ $\mathrm{kg} / \mathrm{ha}$ ). Clear disparity in grain yield was noticed between zinc and sulphur treatments. Among all the zinc treatments tried, $\mathrm{ZnSO}_{4}$ @30 kg resulted in higher grain yield (873 $\mathrm{kg} / \mathrm{ha}$ ) irrespective of zinc management practices, $S$ (40 kg/ha) resulted in higher grain yield $(998 \mathrm{~kg} / \mathrm{ha})$. All nutrient treatments provided significantly higher straw yield compared to the treatment of control. Straw yield among the different treatments was significantly higher in $\mathrm{T}_{16}\left(\mathrm{RNP}+\mathrm{ZnSO}_{4}\right.$ @30kg + S @40 kg/ha) (3145 kg/ha) as compared to other nutrient treatments, which was at par with $\mathrm{T}_{13}\left(\mathrm{RNP}+\mathrm{ZnSO}_{4} @ 20 \mathrm{~kg}+\right.$ $\mathrm{S} @ 40 \mathrm{~kg} / \mathrm{ha})$.

Sulphur of chloroplast protein resulted in greater photosynthetic efficiency which in turn translated in terms of increase in yield (Karche at el., 2012). Similar results were also reported by Singh and Mann (2007) and Baviskar et al., (2010). Zinc play an important role in biosynthesis of indole acetic acid which is responsible for initiation of primodial for reproductive parts and partitioning of photosynthesis towards them which resulted in better yield (Srivastava et al., 2006, Ram and Katiyar, 2013).

Application of $\mathrm{T}_{16}, \mathrm{~T}_{15}, \mathrm{~T}_{13}$ and $\mathrm{T}_{12}$ treatments increased the grain yield by $32.58,32.33$, 32.21 and 29.34 percent and straw yield by $25.9,24.9,25.78$ and 24.70 percent, respectively over control i.e., $\mathrm{T}_{1}$ treatment (Fig. 1). Even in treatment T6 and T7 where sulphur is applied @ 30 and $40 \mathrm{~kg} / \mathrm{ha}$ (along with recommended dose of $\mathrm{N}$ and $\mathrm{P}$ ) respectively, gave 23.35 and 24.59 percent higher grain yield and 15.81 and 18.49 percent higher straw yield respectively over control.

Significantly higher harvest index of $25.89 \%$ was observed with application of $\mathrm{T}_{8}(\mathrm{RNP}+$ $\mathrm{ZnSO}_{4} @ 10 \mathrm{~kg}+\mathrm{S} @ 20 \mathrm{~kg} / \mathrm{ha}$ as compared to control $(24.28 \%)$. It may be attributed to the fact that gypsum as sulphur source possibly enhances sulphur availability faster to plants as compared to control. Similar results were found by Yadav (2004) and Kumawat et al., (2006).

\section{Effect of Zn and S on Economics}

Highest total cost of cultivation was recorded in $\mathrm{T}_{16}\left(\mathrm{RNP}+\mathrm{ZnSO}_{4} @ 30 \mathrm{~kg}+\mathrm{S} @ 40 \mathrm{~kg} / \mathrm{ha}\right)$ (Rs 22439/ha) followed by $\mathrm{T}_{15}\left(\mathrm{RNP}+\mathrm{ZnSO}_{4}\right.$ @30 kg+S@30 kg/ha) (Rs 22139/ha).

Highest gross returns was observed in $\mathrm{T}_{16}$ $\left(\mathrm{RNP}+\mathrm{ZnSO}_{4} @ 30 \mathrm{~kg}+\mathrm{S} @ 40 \mathrm{~kg} / \mathrm{ha}\right)(\mathrm{Rs}$ $51436 /$ ha) followed by $\mathrm{T}_{13}\left(\mathrm{RNP}+\mathrm{ZnSO}_{4}\right.$ @20 kg + S @40 kg/ha) (Rs 51325/ha). Highest net returns was observed in $\mathrm{T}_{10}$ (RNP 
$\left.+\mathrm{ZnSO}_{4} @ 10 \mathrm{~kg}+\mathrm{S} @ 40 \mathrm{~kg} / \mathrm{ha}\right)$ (Rs 29576/ha) followed by $\mathrm{T}_{9}\left(\mathrm{RNP}+\mathrm{ZnSO}_{4}\right.$ @10 kg + S @30 kg/ha) (Rs 29534/ha). Highest benefit-cost ratio was observed in $\mathrm{T}_{9}$ $\left(\mathrm{RNP}+\mathrm{ZnSO}_{4} @ 10 \mathrm{~kg}+\mathrm{S} @ 30 \mathrm{~kg} / \mathrm{ha}\right)$ (2.38) followed by $\mathrm{T}_{10}\left(\mathrm{RNP}+\mathrm{ZnSO}_{4} @ 10 \mathrm{~kg}\right.$ + S @ 40 kg/ha) (2.37). Lowest gross returns, net returns and B: $\mathrm{C}$ were observed in control treatment (Table 3). Application of higher doses of $\mathrm{Zn}$ and $\mathrm{S}$ gave better results in terms of gross returns, net returns and in B: C. This was due to comparatively more increase in yield was obtained under $S$ treatment (Baviskar at el., 2010). These results are in accordance with the findings of Jat et al., (2006) and Singh and Mann (2007).

Based on the results of experiment, it can be concluded that $\mathrm{T}_{16}\left(\mathrm{RNP}+\mathrm{ZnSO}_{4} @ 30 \mathrm{~kg}+\mathrm{S}\right.$ @40 kg/ha) resulted in better growth parameters, yield attributes and yields, and economics except harvest index higher in $\mathrm{T}_{8}$ $\left(\mathrm{RNP}+\mathrm{ZnSO}_{4} @ 10 \mathrm{~kg}+\mathrm{S} @ 20 \mathrm{~kg} / \mathrm{ha}\right)$, and net returns higher in $\mathrm{T}_{10}\left(\mathrm{RNP}+\mathrm{ZnSO}_{4}\right.$ @10kg + S @40 kg/ha). So clusterbean crop has shown immense potential to respond toward $\mathrm{Zn}$ and $\mathrm{S}$ fertilization. Application of $\mathrm{Zn}$ and $\mathrm{S}$ with recommended dose of $\mathrm{N}$ and $\mathrm{P}$ improved the growth parameters, yield attributes and yields, and economics.

\section{References}

Anonymous, (2012) Directorate of Economics and statistics, Department of Agricultural and Cooperation New Delhi. India, Annual progress report.

Anonymous, (2013) All India coordinated Research Project on Arid Legumes, NBPGR, New Delhi. Annual progress report.

Aykroyd, W.R., Gopalan, C., \& Balasubramanian, S. C. (1963) The nutritive value of Indian Foods and the planning of satisfactory diets. (6th revised ed). Special report No. 42.
Indian Council of Medical Research, New Delhi.

Baviskar, V.S., Damame, H.S., Raj, V.C. and Shete, P.G. (2012) Growth, yield and quality parameters of clusterbean [Cyamopsis tetragonoloba (L.) Taub.] as influenced by organic fertilizers and different levels of sulphur for vegetable purpose. Crop Research. 43 (1, 2 \& 3): 52-54.

Baviskar, V.S., Shete, P.G. and Daspute, R.A. (2010) Response of summer clusterbean [Cyamopsis tetragonoloba (L.) Taub.] to organic fertilizers and different levels of sulphur for vegetable purpose. International Journal of Agricultural Sciences. 6 (2): 456-458.

Hilal, M. H. and Abd Elfattah, A. (1987) Effect of $\mathrm{CaCO} 3$ and clay content of alkaline soils in their response to added sulphur. Sulphur Agriculture. 11:15-19.

Jat, N.L., Jain, N.K. and Choudhary, G.R. (2006) Intergated nutrient management in fenugreek (Trigonella foenumgraecum L.). Indian Journal of Agronomy. 51 (4): 331-333.

Jordan, H.V., and Reisenauer, H.M. (1957) Sulphur and soil fertility. In: Soil, the Yearbook of Agriculture. USDA. 107111.

Karche, R.P., Dalwadi, M.R., Patel, J.C., Hirparaand, B.V. and Panchal, D.B. (2012) Response of phosphorus and sulphur application on yield quality, nutrient content and nutrient status of soil by cluster bean grown on typic ustochrept of Anand. Asian Journal of Soil Science. 7(2):249-252.

Kasturikrishana, S. and Ahlawat, I.P.S. (2000) Effect of moisture stress, phosphorus, sulphur and zinc fertilizers on growth and development of pea (Pisum sativum). Indian Journal of Agronomy. 45 (2): 353-356.

Kumawat PD, Jat NL, Yadvi SS. (2006) Effects of organic manure and nitrogen 
fertilization on growth, yield and economies of barley. Indian Journal of Agricultural Science. 76: 226-229.

Kumhar, M.K., Patel, I.C. and Shaukat, Aliz. (2012) Integrated nutrient management in clusterbean (Cyamopsis tetragonoloba L.). Legume Research. 35: 350-353.

Meena, K.R., Dahama, A.K. and Reager, M.L. (2006) Effect of phosphorus and zinc fertilization on growth and quality of clusterbean (Cyamopsis tetragonoloba (L.) Taub.). Annual Agricultural Research, New Series. 27 (3): 224-226.

Mousavi, S.R. (2011) Zinc in crop production and interaction with phosphorus. Australian Journal of Basic and Applied Sciences. 5: 1503-1509.

Ram, S. and Katiyar, T.P.S. (2013) Effect of sulphur and zinc on the seed yield and protein content of summer mungbean under arid climate. I.J.S.N. 4(3): 563566.

Ramawtar, A.C. Shivran and Yadav, B.L. (2013) Effect of NP fertilizers, vermicompost and sulphur on growth, yield and quality of clusterbean [Cymopsis tetragonoloba (L.)] and their residual effect on grain yield of succeeding wheat [Triticum aestivum (L.)]. Legume Research. 36 (1): 74-78.

Singh, K. and Raj (2001) Effect of micronutrients application on the yield of Clusterbean in a type torrpsamment. Legume Research. 24(1): 67-68.

Singh, R. Kumar, A. and Kumar, P. (2014) Performance of Indian mustard (Brassica juncea L.) in response to integrated nutrient management. Journal of Agriculture research. 1(1), 9-12.

Singh, Y.P. and Mann, J.S. (2007) Interaction effect of sulphur and zinc in groundnut and their availability in Tonk district of Rajasthan. Indian Journal of Agronomy. 52 (1): 70-73.

Srivastava, A.K., Tripathi, P.N., Singh, A.K. and Singh, R. (2006). Effect of Rhizobium inoculation, sulphur and zinc on growth, yield, nutrient uptake and quality of summer green gram (Phaseolus aureus L.). Indian Journal of Agricultural Sciences, 2(1): 190-192.

Yadav, S.S. (2004)). Growth and yield of greengram (Vigna radiata) as influenced by phosphorus and sulphur fertilization. Haryana Journal Agronomy, 20: 10-12.

\section{How to cite this article:}

Sunil, Seema Dahiya, M.S. Bhattoo and Rajbir Singh Khedwal. 2017. Effect of Zinc and Sulphur on Growth, Yield and Economics of Clusterbean [Cyamopsis tetragonoloba (L.) Taub.]. Int.J.Curr.Microbiol.App.Sci. 6(11): 3744-3751. doi: https://doi.org/10.20546/ijcmas.2017.611.438 